\title{
Posiedzenie Komisji Bizantynologicznej Polskiego Towarzystwa Historycznego (KB PTH) (Lublin, 23 XI 2019)
}

W sobotę, 23 listopada 2019 roku w Katolickim Uniwersytecie Lubelskim Jana Pawła II (Collegium Joannis Pauli II, Aleje Racławickie 14, aula C-1031) odbyło się pierwsze i jedyne w roku akademickim 2019/2020 posiedzenie Komisji Bizantynologicznej PTH. W spotkaniu lubelskim wzięło udział 28 osób. Posiedzenie rozpoczęło się o godzinie 11:35. Otworzył je przewodniczący KB PTH prof. dr hab. Maciej Kokoszko. Powitał on wszystkich obecnych, a następnie krótko scharakteryzował najnowsze polskie publikacje z zakresu bizantynistyki. Następnym punktem programu był wybór nowego przewodniczącego Komisji (11:45-11:55). $\mathrm{Z}$ sali podano trzy kandydatury. W porządku alfabetycznym: (1) prof. dr hab. Kazimierz Ilski, dotychczasowy wiceprzewodniczący KB PTH oraz urzędujący dziekan Wydziału Historycznego Uniwersytetu im. Adama Mickiewicza w Poznaniu i członek Sekcji Bizantynologicznej KNoKA PAN; (2) prof. dr hab. M. Kokoszko, dotychczasowy przewodniczący KB PTH oraz urzędujący dziekan Wydziału Filozoficzno-Historycznego Uniwersytetu Łódzkiego, kierownik Katedry Historii Bizancjum UŁ i członek Sekcji Bizantynologicznej Komitetu Nauk o Kulturze Antycznej PAN; (3) prof. dr hab. Mirosław J. Leszka (Uniwersytet Lódzki). W głosowaniu tajnym prof. M. Kokoszko otrzymał 16 głosów, prof. K. Ilski 4 głosy, prof. M.J. Leszka - także 4 głosy. W sumie w głosowaniu brały udział 24 osoby. Nie głosowali trzej kandydaci na członków Komisji oraz jedna osoba będąca ,sympatykiem” KB PTH. W wyniku wyborów prof. M. Kokoszko został przewodniczącym Komisji na kolejną kadencję. Zaproponował też, aby wiceprzewodniczącym Komisji pozostał prof. K. Ilski, a sekretarzem - dr Andrzej Kompa, prodziekan ds. jakości kształcenia Wydziału Filozoficzno-Historycznego UŁ. Ponieważ zaproponowani kandydaci wyrazili zgodę, zatem prezydium KB PTH będzie pracować w nowej kadencji w tym samym co poprzednio składzie: przewodniczący - prof. M. Kokoszko; wiceprzewodniczący - prof. K. Ilski; sekretarz - dr A. Kompa. Rozwiązanie to zebrani zaakceptowali przez aklamację, wyra- 
żając tym samym uznanie dla pracy tegoż składu Komisji w poprzedniej kadencji.

Następnie (11:55-12:10) przyjęto nowych członków KB PTH, którymi zostali (1) dr Marcin Grala (adiunkt w Katedrze Europy Środkowej i Wschodniej na Wydziale Historii i Dziedzictwa Kulturowego Uniwersytetu Papieskiego Jana Pawła II w Krakowie), którego rekomendował prof. dr hab. Maciej Salamon; (2) dr Bogna Kosmulska (adiunkt w Zakładzie Historii Filozofii Starożytnej i Średniowiecznej na Wydziale Filozofii i Socjologii Uniwersytetu Warszawskiego), rekomendowana przez ks. prof. dr. hab. Józefa Naumowicza (tekst listu polecającego odczytał dr hab. Sławomir Bralewski, prof. UŁ); (3) dr Konrad Kuczara (adiunkt na Wydziale „Artes Liberales” UW), którego rekomendował dr A. Kompa. Wszystkie kandydatury zostały przyjęte jednogłośnie.

Kolejnym punktem programu (12:10-12:20) było przyjęcie logotypu Komisji. Przedstawiono cztery propozycje. Spośród nich wybrano logotyp, który roboczo określono mianem „Archanioł z Lublina”, ponieważ źródłem jego inspiracji był wizerunek archanioła Gabriela z bizantyńsko-ruskiego fresku przedstawiającego zwiastowanie. Fresk ten znajduje się w Kaplicy Trójcy Świętej stanowiącej część Muzeum Lubelskiego w Lublinie. Freski te zostały ufundowane przez króla Władysława Jagiełłę w 1418 roku. Przyjęty logotyp będzie nie tylko emblematem KB PTH, lecz także emblematem Polskiego Komitetu Narodowego, który wchodzi w skład Association Internationale des Études Byzantines. Jego autorką jest mgr Agnieszka Piórecka, która jest członkiem KB PTH.

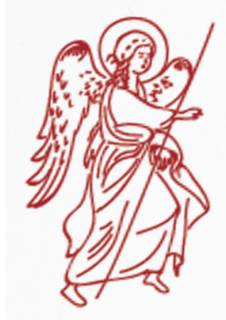

Następnie (12:20-12:45) podjęto dyskusję na temat ministerialnej listy czasopism odnoszącej się do starożytności i średniowiecza: chodziło z jednej strony o niepełność rzeczonej listy, z drugiej zaś o liczbę punktów przyznanych poszczególnym czasopismom. Zagadnienie to zreferował dr A. Kompa, twórca stosownego wyciągu z listy czasopism punktowanych 
MNiSW. Wyciąg ten został przez autora wysłany (14 listopada 2019) drogą elektroniczną wszystkim członkom Komisji. W dyskusji nad tym zagadnieniem głos zabrali kolejno prof. M. Kokoszko, dr hab. Jacek Bonarek (prof. UJK w Kielcach, Filia w Piotrkowie Trybunalskim) i prof. K. Ilski. W tej sprawie postanowiono jednogłośnie o wysłaniu do Ministerstwa rezolucji, którą ma zredagować dr A. Kompa, jako sekretarz KB PTH. Po dyskusji dr Jan M. Wolski przypomniał zebranym, że między 24 a 26 kwietnia 2020 roku odbędzie się w Łodzi Second Colloquia Ceranea International Conference. Tytuły wystąień można było zgłaszać do 15 stycznia 2020. Po tym krótkim komunikacie przewodniczący ogłosił przerwę (12:45-13:05).

Po tej chwili wytchnienia przyszła kolei na dwa referaty. Autorem pierwszego z nich był ks. dr hab. Piotr Szczur, prof. KUL, który mówił na następujący temat: „Problem bogactwa w myśli Jana Chryzostoma” (13:05-13:40). Po prelekcji miała miejsce dyskusja (13:40-14:00), w której głos zabrali kolejno prof. M. Kokoszko, prof. K. Ilski, dr Piotr Ł. Grotowski (UPJPII Kraków), dr hab. Mirosław P. Kruk (prof. UG), dr Sławomir Skrzyniarz (UJ), prof. Marek Wilczyński (UP KEN Kraków), dr B. Kosmulska (UW) i dr Adrian Szopa (UP KEN Kraków). Drugi referat przedstawił wspomniany wyżej prof. M.P. Kruk (14:00-14:30). Temat jego wystąpienia brzmiał następująco: „Problematyka genezy jagiellońskiej fundacji Graeco opere”. W dyskusji (14:30-14:50) zaś wzięli udział następujący badacze: dr P.Ł. Grotowski, dr A. Kompa, dr M. Grala, prof. K. Ilski i dr hab. M. Blaza SJ (Papieski Wydział Teologiczny „Bobolanum”). Ponieważ nikt nie zgłaszał tzw. wolnych wniosków, zatem spotkanie KB PTH zakończono o godzinie 14:50, po czym jego uczestnicy udali się na wspólny obiad. „Technicznymi” organizatorami lubelskiego spotkania Komisji byli ks. dr hab. P. Szczur (prof. KUL) oraz niżej podpisany.

Zwykle KB PTH spotyka się dwa razy w ciągu danego roku akademickiego, tj. w listopadzie i na początku czerwca. Ponieważ jednak w tym roku akademickim z powodu tzw. epidemii koronawirusa zajęcia uniwersyteckie przerwano w środę, 11 marca 2020, przechodząc jednocześnie na nauczanie zdalne, zatem spotkanie czerwcowe, które miało się odbyć w Łodzi, nie doszło do skutku. 